Ann. Biol. anim. Bioch. Biophys., 1978, 18 (2 B), 511-521.

\title{
Permeability of ovarian follicle ; corona cell-oocyte relationship in mammals
}

\author{
by D. SZÖLLÖSI, M. GÉRARD, Y. MÉNÉZO *, C. THIBAULT ** \\ Station centrale de Physiologie animale, I. N. R. A., 78350 jouy-en-josas. \\ * Laboratoire de Biologie, I. N. S. A., 69621 Villeurbanne. \\ ** Université Pierre ef Marie Curie, 75005 Paris.
}

Summary. Graafian follicles incubated in toto with electron dense markers, such as horseradish peroxidase and lanthanum nitrate were penetrated freely by the tracers through the granulosa cells and the cumulus oophorus, reaching the oocyte. It seems thus that no blood-follicle barrier exist.

The corona cell foot-processes which traverse the zona pellucida form gap junctions with the oocyle. The integrity of the junctions is retained in the rabbit until 4-4 $1 / 2 \mathrm{hrs}$ after LH release; later on they are fully interrupted. During the same period of time cortical granules remain in the subcortical ooplasm, often in clusters. These granules migrate into the proximity of the inner leaflet on the egg plasma membrane about 4-41/2 hrs after $\mathrm{LH}$ release. $\mathrm{LH}$ release and the subsequent elimination of the gap junctions between corona cell foot processes and the oocyte control either in a direct or indirect manner the cytoplasmic maturation of the egg cortex.

The mammalian ovarian follicle proper is avascular and hence every substance from oxygen to hormones which reach it, must diffuse in the extra-cellular spaces from the vascular bed of the theca interna and must pass across a basal lamina, and between the often densely packed granulosa cell layer. Therefore it is important to know if at the border of the follicle a molecular filtration barrier exists similar to that existing in the testis of mammals (Dym and Fawcett, 1970) and some insects (Szöllösi A. and Marcaillou, 1977).

In the first part of this study we examine this question by electron microscopy by employing macromolecular markers in porcine and bovine follicles in short term culture.

In the second part of our report the recently discovered gap junctions between the cells of the corona radiata and oocyte will be considered (Anderson and Albertini, 1976 ; Gilula, 1976 ; Szöllösi, 1975). Our studies suggest that the cortical maturation of the oocyte is closely linked to release of luteinizing hormone (LH) and to the interruption of the oocyte-corona cell gap junctions. 


\section{Materials and methods.}

Pig follicles were isolated the third day after methallibure treatment was stopped and subsequent to an intramuscular injection of $1000 \mathrm{Ul}$ of Pregnant Mare Serum Gonadotrophin (PMSG) (Polge et al., 1968). The largest follicles of 3 to 4 month-old calves were removed following progesterone and PMSG treatment (Thibault et al., 1976). Both were cultured for $3-4$ hrs in B2 medium (Ménézo, 1976) containing $10 \mathrm{mg} / \mathrm{ml}$ horseradish peroxidase (Type II, Sigma) and gased continuously with 57 p. $100 \mathrm{O} 2$, 5 p. 100 CO2, 38 p. 100 N2. The peroxidase was localized by the method of Novikoff et al. (1971) after glutaraldehyde fixation on small follicle fragments. Follicles were also fixed in toto with the addition of lanthanum nitrate (Revel and Karnovsky, 1967).

For studies on the corona cell-oocyte relationship oocytes were removed from the largest follicles of previously mated rabbits at time of mating and at hourly to half hourly intervals there after until ovulation. Oocytes of calf follicles matured in vitro (Ménézo et al., 1976) were also studied. All the cumuli were fixed in 2.5 p. 100 glutaraldehyde and 0.75 p. 100 paraformaldehyde solution in $0.15 \mathrm{M}$ cacodylate buffer containing $0.05 \mathrm{M}$ polassium ferricyanide (Elbers ef al., 1965), post osmicated and prepared by the usual methods for electron microscopy. In somes case the tissues were placed into a 2 p. 100 uranyl acetate solution for one hour following osmication.

\section{Results and discussion.}

\section{Blood-follicle barrier.}

Examination of semi-thin sections of plastic embedded porcine and bovine follicles (fig. 1 and 2) lead to the view that the theca interna actually is composed of two layers: a) a vascular layer, several microns thick along the basal lamina of the follicle, containing capillaries, a few endocrine cells, semetimes clustered, and fibroblasts; b) a glandular layer, composed of endocrine cells and capillaries.

In fact the ovarian hormones secreted by the cells of the glandular layer of the theca interna can reach the follicle by way of the interstitial fluid and do not have to enter at first the circulatory system. The capillaries in the vascular layer, thus,

FIG. 1-2. - Semi-thin sections of porcine and bovine follicular wall respectively adjacent to the cumulus oophorus. The vasculature traverses the distal portion of the theca interna radially becoming finally paralle with the basment membrane of the follicle. The darkly staining glandular cells are intermixed with fibroblasts and capillaries. The layer marked with a star is considered as the vascular layer of the theca interna.

FIG. 3. - Red and white blood cells, which escaped from the capillary bed in a porcine follicle are found in the interstitial spaces in close proximity of the bosal lamina of the follicle. 

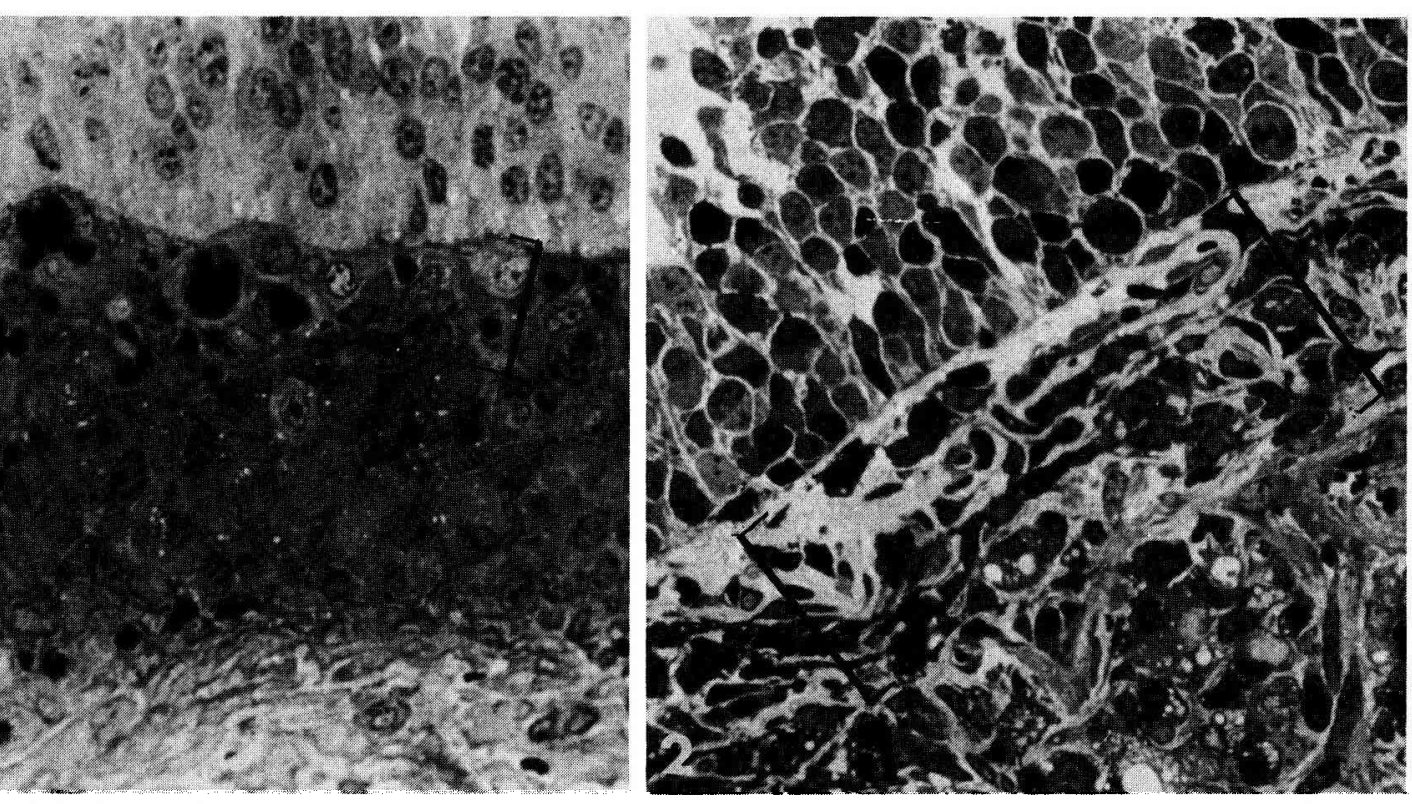

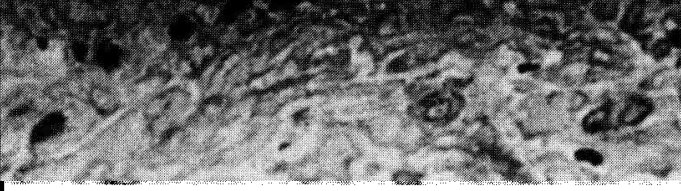

(7) 3a) 3 . 186.

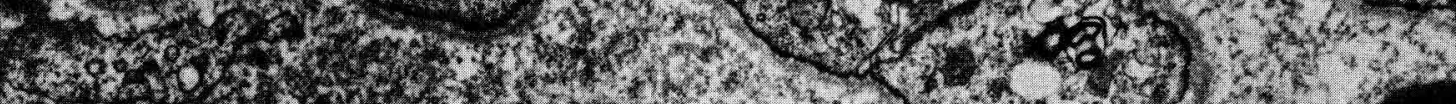

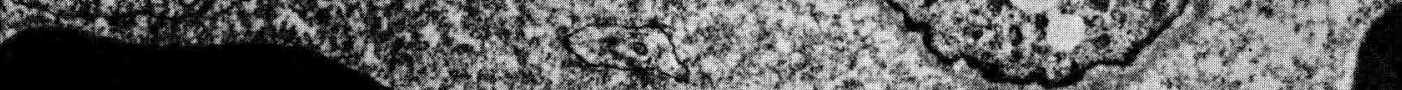

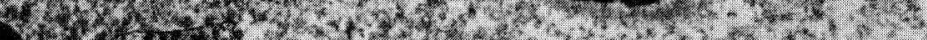

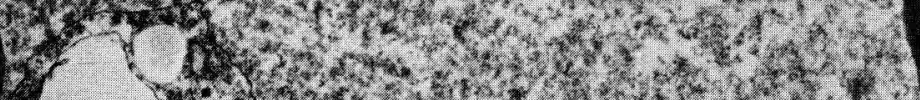
20.8. 27. (2)

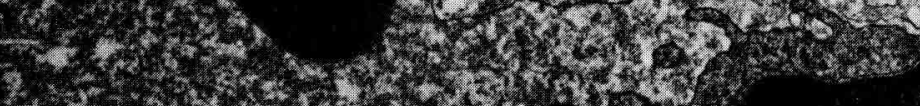<smiles>[13CH][13CH3]</smiles>

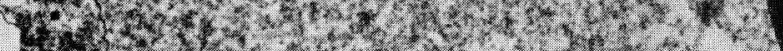

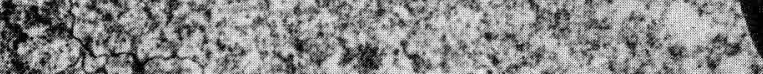

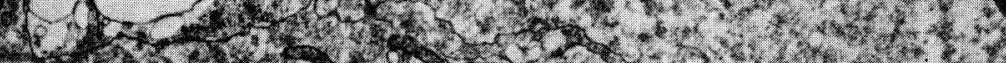

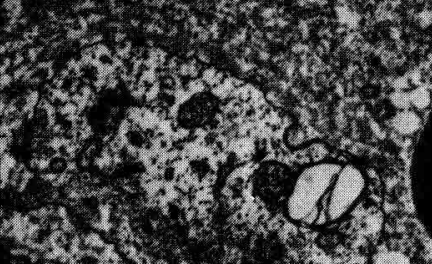
6.

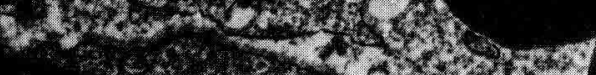

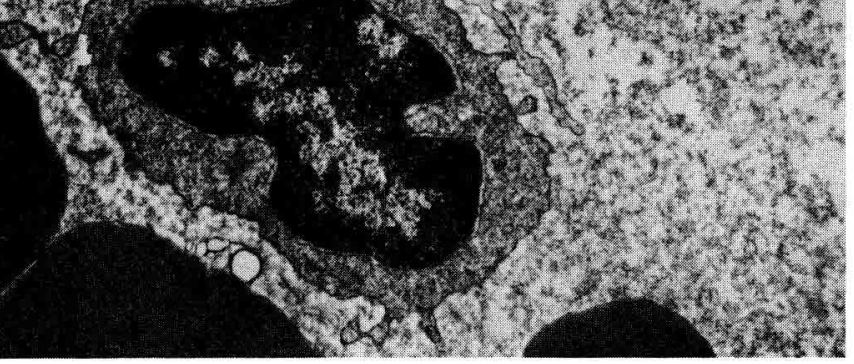


would serve primarily for supplying the follicle with oxygen and chemicals absorbed or produced at other sites of the body.

The vascular layer of the porcine ovary is particular in that its capillaries are not fully continuous but large fenestrations develop between the endothelial cells, representing its lining. The spaces are large enough that cellular elements may leave the vascular bed in addition to plasma (fig. 3). The follicle is thus surrounded by large blood lakes which abutt diretly against the basal lamina of the follicle (Comer, 1919 ; Daguet, 1978). The molecular components transported by the plasma need thus to traverse only the thin, felt-like basal lamina (30 $\mathrm{nm}$ approximatelly) until they make contact with the first follicle cells composing the membrana granulosa.

It is well known that the follicle cells are electrically and (most likely) metabolically coupled by large gap junctions (Albertini and Anderson, 1974 ; Bjersing and Cajander, 1974 ; Albertini ef al., 1975 ; Amsterdam et al., 1975 ; Anderson and Albertini, 1976 ; Gilula, 1977 ; Zamboni, 1974) whose frequency and size appears to be hormonally controlled (Merk ef al., 1972). Towards the basal lamina the membranes of the adjacent cells of the granulosa appose very closely forming, which might appear to be, tight junctions by transmission electron microscopy. The existence of tight junctions would seem to be incongrous with physiological experiments which indicate that plasma proteins of very large size (in the neighbourhood of $10^{6}$ Daltons) have access to the follicular fluid in vivo (Shalgi et al., 1973). Under organ culture conditions, large proteins found in the follicular fluid may pass into the culture medium (Ménézo et al., 1978). Experiments employing macromolecular markers in electron microscopy confirm that a blood-follicle barrier does not exist. If truely present, tight junctions between granulosa cells would be either apparent or focal thus permitting the interstitial fluid to have fairly free passage in and out of the follicle (Cran et al., 1976). Figure 4 illustrates this aspect in pig follicles employing horseradish peroxidase as marker. The results obtained by employing lanthanum nitrate coincide fully with those obtained with peroxidase.

\section{Corona cell-oocyte relationship.}

Every cell within the follicle is coupled by gap junctions, including the cells of the corona radiata and the oocyte (Anderson and Albertini, 1976 ; Gilula, 1977 ; Szöllösi, 1975). The button-like terminals of the corona cells are attached to the oocyte by a further junctional complex which is morphologically of the intermediate junction type (macula adherens) and may serve a structural role (figs 5,6 ). The gap junctions between the follicle cells and oocyte are focal, probably small discs, measuring between $100-200 \mathrm{~nm}$ in diameter. That molecular exchange is possible across these

FIG. 4. - The basal lamina and granulosa cells of a porcine ovarian follicle demonstrate the passage and distribution of horseradish peroxidase throughout the follicle. The heavily staining layer is the basal lamina (BL) with a few adjacent collagen fibers.

FIG. 5-6. - Foot processes of rabbit and bovine corona radiata cells (CR) form small gap junctions with the oocyfe (O) cell membrane (arrows). The adjacent felt-like material may correspond to an intermediate junction. 

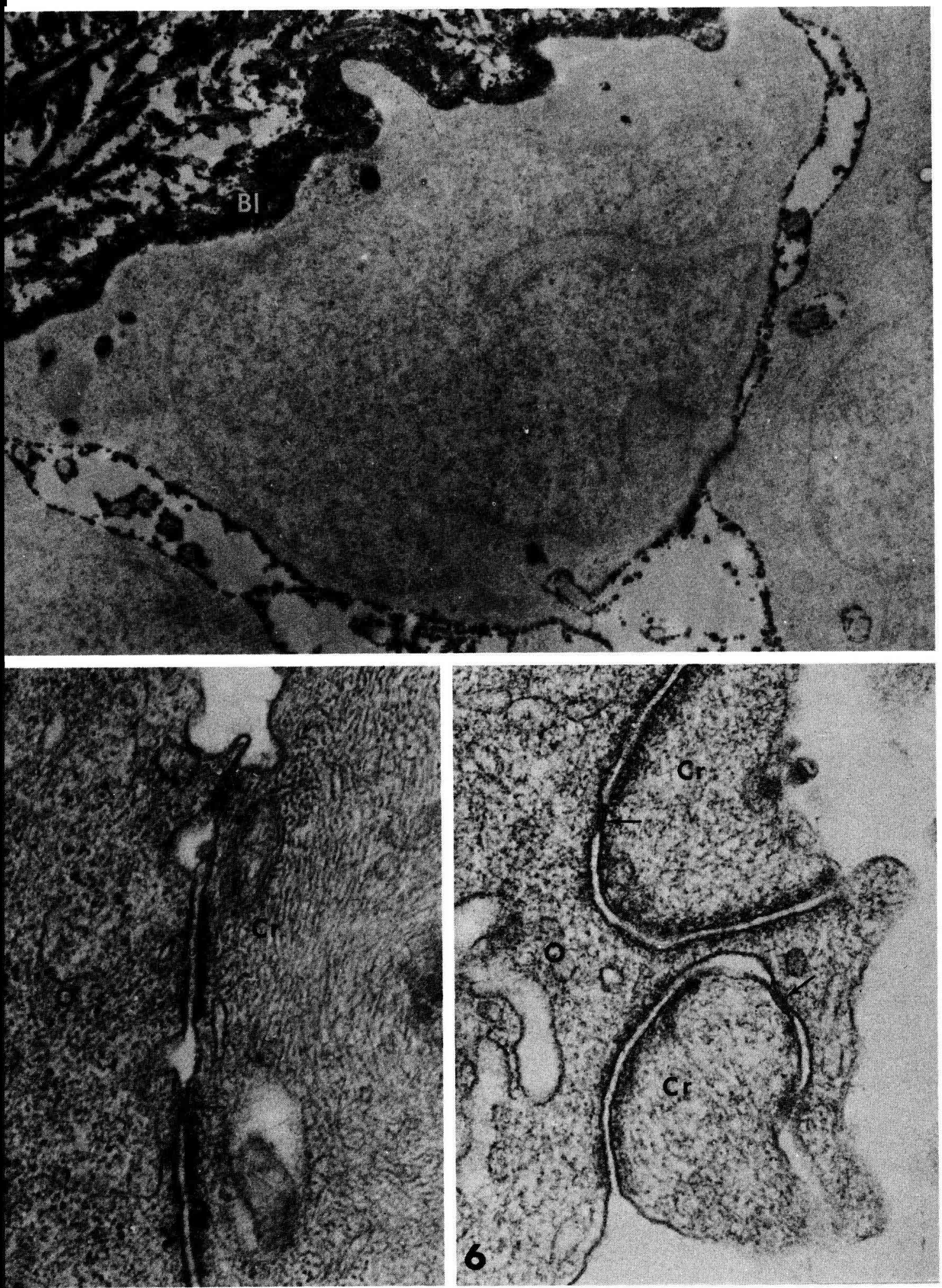

2
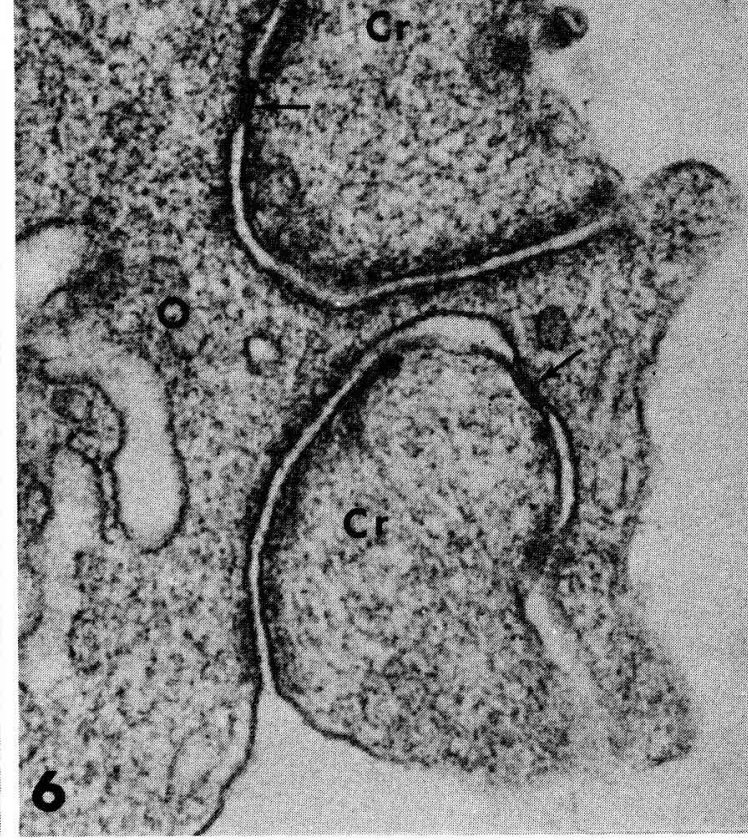
junctions has been demonstrated recently by injecting fluorescein into rat oocytes and following its spread, little by little, into the surrounding cumulus cells (Epstein ef al., 1976). In rabbits, in which LH release follows copulatory stimulus, by one hour, it has been demonstrated that approximatelly 5-5 $1 / 2 \mathrm{hrs}$ after copulation the gap junctions between corona cells and oocyłe are interrupted (Szöllösi, 1975). The gap junctions are eliminated also in cultured bovine follicles when a preliminary culture of $24 \mathrm{hrs}$ duration with PMSG is continued for an additional $24 \mathrm{hrs}$ after the medium was supplemented with Human Chorionic Gonadotropin (HCG). The exact time when the junctional complexes are interrupted has not yet been defermined under culture conditions. In case of follicles cultured for $48 \mathrm{hrs}$ with PMSG alone the gap junction between corona and oocyte are retained.

\section{Cortical maturation of oocyte.}

Other than the potential passage of molecules no information exists for the metabolic role the junctions may play in the life-history of the oocyte. It seems to be a general observation that maturation implies the reduction or even cessation of corona-oocyte association ; the same holds true for the junctions found between all the peri-oocyte cells. What may the metablic isolation of the oocyte from its surrounding cells mean?

From the many possible roles the gap junctions may play we have indications as to one : the control of cortical maturation of the oocyte depends on or is time wise correlated with the interruption of the gap junctions.

Cortical granules are formed in different mammals in different stages of oocyte maturation by the multiple and widely dispersed Golgi units (Szöllösi, 1967 ; Zamboni, 1970 ; Selman and Anderson, 1975). In rabbit and bovine oocytes the majority of these granules are formed toward's the end of the oocyte growth phase. The formed granules tend to cluster in the sub-cortical cytoplasm or may be found individually scattered throughout the ooplasm (figs. 7,8 ). In oocytes recovered during the follicular phase, cortical granules do not move to the proximity of the oocyte celle membrane (fig. 9), where they are localized at time of ovulation. In closely timed series it has been shown in rabbit oocytes that cortical granules populate the egg cortex only between 6-6 1/2 hrs after mating (fig. 10); this process follows timewise or coincides with the interruption of gap junctions between the corona cells and oocyte. The changes at the cell membrane level may be coordinated with the over all shape change of the corona cells which elongate drastically and are lifted from the surface

FIG. 7-8. - In the sub-cortical cytoplasm cortical granules (CG) aggregate into clusters in a rabbit egg recovered from a follicle $31 / 2$ hrs after mating and a bovine oocyte recovered from a follicle cultured for 48 hrs with PMSG respectively. A few cortical granules are scattered freely in the egg cytoplasm of the oocyte.

FIG. 9. - A rabbit follicular oocyte isolated $31 / 2$ hrs ofter mating shows several corona cell processes in contact with the oocyie cell membrane. No cortical granules are seen at all adjacent to the plasma membrane. 
of the zona pellucida. The cell processes traversing the zona are withdrown (Thibault, 1972 ; Szöllösi, 1975). Even though the actual time elapsed may slightly differ in the in vivo and in vitro maturation of mouse oocytes, in principal the same phenomenon was observed : cortical granules migrate to their sub-cell membrane position after corona cell-oocyte contacf was terminated (Szöllösi, unpublished).

Under appropriate culture conditions the same process can be reproduced in bovine follicles (Ménézo, 1976 ; Ménézo et al., 1976). If in cultured follicles the perioocyte reaction (elongation of corona cells, withdrawal of foot processes and elimination of gap junctions) does not take place, cortical granules are found in large clusters several microns from the cortex (fig. 8). Within these clusters the diameter of the granules and their density may greatly vary. This holds true regularly for control follicles as well as for those maintained for $48 \mathrm{hrs}$ in culture with PMSG alone.

When, however, HCG was added to the medium during the final $24 \mathrm{hrs}$ of culture the peri-oocyte cell reaction and the interruption of gap junctions have taken place. Under these conditions the centrifugal displacement and alignement of the cortical granules has been noted (fig. 11). The membrane surrounding the cortical granules makes almost contact with the inner leaflet of the oocyte cell membrane (fig. 12), fully parallel to their localisation during in vivo maturation. The absence of cortical granules from the oocyte cortex recovered from cestrus rabbits and the fact that they migrate to the egg periphery during $48 \mathrm{hrs}$ of culture in a medium containing FSH-LH was already noted (Nicosia and Mikhail, 1975). The relationship with the simultaneously occuring reaction of the peri-oocyte cells was, however, not made.

The cortical maluration is an important aspect of oocyte physiology because the cortical granules and the cortical reaction at time of sperm penetration play most probably a role in the defense of polyspermy. In case they were not able to take up their peripheral position, polyspermy would ensue. The gap junctions between corona cells and oocyte seem to inhibit this aspect of cytoplasmic maturation of the mammalian oocyte.

27 e Congrès infernational des Sciences physiologiques, Symposium " Germ and somatic cell interaction 》 Paris, 21-23 juillet 1977.

Acknowledgments. - Supported in part by DGRST Grant no 75.7.1313.

Résumé. Des follicules de de Graaf incubés in toto en présence de traceurs denses aux électrons, tels que la peroxydase de raifort ef le nitrate de lanthane, sont pénétrés par ces traceurs qui, à travers les cellules de la granulosa et du cumulus oophorus, atteignent l'ovocyte. II semble donc qu'il n'existe pas de barrière « sang-follicule ».

Des macrovillosités des cellules de la corona traversent la zone pellucide ef forment des jonctions de type « gap » avec l'ovocyte. Chez la Lapine, ces jonctions subsistent sans

FIG. 10-11. - The cortical granules aligne along the cell membrane. Their size and density is uniform in the rabbit oocyte (fig. 10) but in the oocyte of bovine origin (fig. 11) both parameters may vary.

FIG. 12. - Cortical granules move within a few hundred Angström distance of the oocyfe plasma membrane. 
modification jusqu'à $4 \mathrm{~h}$ à $4 \mathrm{~h} 30$ après la libération de LH. Plus tard, elles sont totalement éliminées. Pendant cette même période, les granules corticaux restent dans l'ooplasme sous-cortical, souvent groupés, migrent vers le feuillet interne de la membrane plasmique de l'ovocyte environ $4 \mathrm{~h}$ à $4 \mathrm{~h} 1 / 2$ après la libération de $\mathrm{LH}$. Cette libération et l'élimination consécutive des jonctions « gap » entre les cellules de la corona et l'ovocyte contrôlent de façon directe ou indirecte la maturation du cortex de l'œuf.

\section{References}

ALBERTINI D. F., ANDERSON E., 1974. The appearance and structure of intercellular connections during the ontogeny of the rabbit follicular follicle with particular reference to gap junction. J. Cell Biol., 63, 234-250.

ALBERTINI D. F., FAWCETT D. W., OLDS P. J., 1975. Morphological variations in gap junctions of ovarian granulosa cells. Tissue and Cell, 7, 389-405.

AMSTERDAM A., JOSEPHS R., LIEBERMAN M. E., LINDNER H. R., 1976. Organization of intermembrane particles in freez-cleaved gap junctions of rat Graafian follicle : optical-diffraction analysis. J. Cell Sci., 21, 93-106.

ANDERSON E., ALBERTINI D. F., 1976. Gap junctions between the oocyte and companion follicle cells in the mammalian ovary. J. Cell Biol., 71, 680-686.

BJERSING L., CAJANDER S., 1974. Ovulation and the mechanism of follicle rupture. IV. Ultrastrucfure of membrana granulosa of rabbit Graafian follicles prior to induced ovulation. Cell Tissue Res., 153, 15-30.

COMER G. W., 1919. On the origin of the corpus luteum of the saw from both granulosa and theca interna. Am. J. Anat., 26, 117-183.

CRAN D. F., MOOR R. M., HAY M. F., 1976. Permeability of ovarian follicles to electron-dense macromolecules. Acta endocrinol., 82, 631-636.

DAGUET M. C., 1978. Some aspects of final follicle growth in the sow. Ann. Biol. anim. Bioch. Biophys. (submitted to publication).

DYM M., FAWCETT D. W., 1970. The blood-testis barrier in the rat and the physiological compartmentation of the seminiferous epithelium. Biol. Reprod., 3, 308-326.

ELBERS P. J., VERVERGAERT P. H. J., DEMEL R., 1965. Tricomplex fixation of phospholipids. J. Cell Biol., 23, 23-30.

EPSTEIN M. L., BEERS W. H., GILULA N. B., 1976. Cell communication between the rat cumulus oophorus and the oocyte. J. Cell Biol., 70, 3020.

GILULA N. B., 1977. Biochemical and morphological characterization of gap junctions. Int. Cell Biol., Symposium H, 61-69.

MÉNÉZO Y., 1976. Milieu synthétique pour la survie ef la maturation des gamètes ef pour la culture de l'œuf fécondé. C. R. Acad. Sci. Paris sér. D, 282, 1967-1970.

MÉNÉZO Y., GÉRARD M., THIBAULT C., 1976. Culfure du follicule de de Graaf de bovin dans un système à courant liquide et gazeux continu. C. R. Acad. Sci. Paris sér. D, 283, 1309-1311.

MÉNÉZO Y., GÉRARD M., SZÖLLÖSI D., THIBAULT C., 1978. In vitro exchange between the follicle and its culture medium. Ann. Biol. anim. Bioch. Biophys., 18, 471-476.

MERK F. B., BOTICELLI C. R., ALBRIGHT J. T., 1972. An intercellular response to estrogen by granulosa cells in the rat ovary; an electron microscope study. Endocrinol., 90, 992-1007.

NICOSIA S. V., MIKHAIL G., 1975. Cumuli oophori in tissue culture : hormone production, ultrastructure, and morphometry of early luteinization. Fertil. Steril., 26, 427-448.

NOVIKOFF A. B., BEARD M. E., ALBALA A., SHEID B., QUINTANA N., BIEMPICA L., 1971. Localization of endogenous peroxidases in animal tissues. J. Microsc., 12, 381-404.

POLGE C., DAY B. N., GROVES T. W., 1968. Techniques for the precise synchronization of ovulation and artificial insemination in pigs. Vet. Rec., 83, 136.

REVEL J. P., KARNOVSKY M. J., 1967. Hexagonal subunits in intracellular junctions of the mouse heart and liner. J. Cell Biol., 33, C7-C12.

SELMAN K., ANDERSON E., 1975. The formation and cytochemical characterization of cortical granules in ovarian oocytes of the golden hamster (Mesocricetus auratus). J. Morphol., 147, 251-274. 
SHALGI R., KRAICER P., RIMON A., PINTO M., SOFERMAN N., 1973. Proteins of human follicular fluid ; the blood-follicle barrier. Fertil. Steril., 24, 429-434.

SZÖLLÖSI A., MARCAILLOU C., 1977. Electron microscope study of the blood-testis barrier in an insect : Locusta migratoria. J. Ultrastr. Res., 59, 158-172.

SZÖLLÖSI D., 1967. Development of cortical granules and the cortical reaction in rat and hamster eggs. Anat. Rec., 159, 431-446.

SZÖLLÖSI D., 1975. Ultrastructural aspects of oocyte maturation and fertilisation in mammals, 13-35. In THIBAULT C. La fécondation, Masson, Paris.

THIBAULT C., 1972. Final stages of mammalian oocyte maturation, 392-411. In BIGGERS J. D., SCHUETZ A. W. Oogenesis, Univ. Parks Press, Baltimore.

THIBAULT C., GÉRARD M., MÉNÉZO Y., 1976. Nuclear and cytoplasmic aspects of mammalian oocyle maturation in vitro in relation to follicle size and fertilization. In HUBINONT P. O., Progr. reprod. Biol., 1, 233-240, S. Karger Press, Basel.

ZAMBONI L., 1970. Ultrastructure of Mammalian oocytes and ova. Biol. Reprod., suppl. 2, 44-63.

ZAMBONI L., 1974. Fine morphology of the follicle wall and follicle cell-oocyte association. Biol. Reprod., 10, 125-149. 